\section{VILNIUS TECH \\ Vilniaus Gedimino technikos universitetas \\ APLINKOS APSAUGOS INŽINERIJA / ENVIRONMENTAL PROTECTION ENGINEERING Proceedings of the 24th Conference for Junior Researchers "Science - Future of Lithuania"}

2021 m. kovo 19 d. Vilnius, Lietuva

19 March 2021, Vilnius, Lithuania

24-osios Lietuvos jaunujų mokslininkų konferencijos „Mokslas - Lietuvos ateitis“ teminè konferencija
ISSN 2029-7157

elSSN 2029-7149

ISBN 978-609-476-270-3

eISBN 978-609-476-271-0

https://doi.org/10.3846/aainz.2021.19

\title{
BIRIŲJŲ TRĄŠŲ GAVIMAS NAUDOJANT IVAIRIAS ORGANINĖS KILMĖS ATLIEKAS
}

\author{
Dovilè Ragauskaité ${ }^{1}$, Rasa Šlinkšienè ${ }^{2}$ \\ Kauno technologijos universitetas, Cheminès technologijos fakultetas, Fizikinès ir neorganinès chemijos katedra \\ El.p. ${ }^{1}$ dovile.ragauskaite@ktu.lt; ${ }^{2}$ rasa.slinksiene@ktu.lt
}

\begin{abstract}
Anotacija. Tarptautinès kavos organizacijos duomenimis, $2020 \mathrm{~m}$. pasaulyje buvo suvartota daugiau negu $10^{7} \mathrm{~kg}$ kavos pupelių. Daugiausia kavos suvartojama Europoje. Pradinio kavos apdorojimo ir gėrimo ruošimo metu susidaro daug įvairių atliekų: kavos uogų minkštimas, sidabrinė odelè, kavos tirščiai. Šiose atliekose yra daug įvairių cheminių elementų, tačiau jos vis dar nèra maksimaliai naudojamos pramoneje antriniams produktams gauti. Šiame darbe ištirtos ir ịvertintos kavos tirščių, susidarančių tiek viešojo maitinimo įstaigose, tiek buityje, naudojimo granuliuotų trąšų gamyboje galimybės. Mokslinių tyrimų metu gauti rezultatai rodo, jog kavos tirščiuose yra ne tik pagrindinių augalų maisto medžiagų: azoto, fosforo bei kalio, tačiau juose aptinkama ir antrinių (kalcio, magnio, sieros) ir mikroelementų pedsakų. Šio tyrimo metu iš kavinių surinkti kavos tirščiai buvo granuliuojami laboratoriniu būgniniu granuliatoriumi-džiovykla, papildomai iš anksto jų neapdorojus, t. y. nedžiovinus. Tokiu būdu siekiama išvengti papildomų energinių sąnaudų ir supaprastinti sandèliavimo sąlygas. Granulèms gauti buvo naudojami ịvairios drèkinamosios-rišamosios medžiagos (vanduo, ortofosforo rūgštis ir kt.). İvertinant maisto medžiagų poreikị augaluose, granuliuotoms trąšoms keliamus reikalavimus ir vien tik kavos tirščiu granuliavimo rezultatus, buvo parinkti ir į granuliuoti ruošiamą žaliavų mišinị dedami kitu organinès kilmès medžiagų priedai. Tyrimo metu nustatytos gauto granuliuoto produkto fizikinès savybės: granuliometrinè mišinio sudètis, piltinis tankis, drègmès kiekis, prekinès frakcijos granulių stipris bei $10 \%$ vandeninio tirpalo $\mathrm{pH}$ vertès.
\end{abstract}

Reikšminiai žodžiai: kavos tirščiai, grikių lukštų pelenai, biriosios trąšos, melasa, granuliavimas.

\section{Ivadas}

Tarptautinès kavos organizacijos duomenimis, 2019$2020 \mathrm{~m}$. pasaulyje buvo suvartota daugiau negu $10 \mathrm{mlrd}$. kilogramų kavos, iš kurių daugiau negu trečdalis suvartojama Europoje (International Coffee Organization, 2021). Dèl intensyvaus jos vartojimo kavos pramonejje susidaro didžiulis kiekis atliekų, kurių didžioji dalis dažniausiai nèra tinkamai naudojama.

Ruošiant kavos gèrimą, sunaudotam $1 \mathrm{~g}$ maltos kavos tenka apie 0,91 g tirščių. Mokslininkai plačiai analizuoja kavos tirščių naudojimo galimybes įvairiose pramonès šakose: biodyzelino, bioetanolio gamyboje, maisto pramonèje (Blinová et al., 2017). Dèl didelio kaloringumo kavos tirščiai dažnai naudojami kaip kuras (Nosek et al., 2020). Taip pat jie gali būti naudojami kaip substratas grybams auginti (Leifa et al., 2001).

Labai nedaug mokslinių tyrimų atlikta analizuojant kavos tirščių naudojimą trąšų pramonejje, taip pat ir jų taikymą bei poveiki augalams auginant juos pramoniniu būdu, o ne namuose. Atliktų tyrimų metu pastebèta, jog kavoje yra ne tik elementų, reikalingų augalams augti, bet ir aptinkama junginių, kurie augalams daro neigiamą poveiki (Gomes et al., 2013). Kavos tirščių, kaip ir paties kavos gèrimo, cheminė sudètis priklauso nuo ịvairiausių veiksnių, vienas pagrindinių - ekstrakcijos efektyvumas, kurị lemia kavos pupelių auginimo sąlygos, kokybė, apdorojimo būdas, skrudinimo režimas, sumalimo laipsnis, gèrimui ruošti naudojamo vandens kokybè, temperatūra, slègis ir daugelis kitų (Blinová et al., 2017).

Augalams augti itin svarbi tirščiuose esanti kofeino, chlorogeninès rūgšties ir taninų koncentracija. Mokslininkų teigimu, būtent šie junginiai daro neigiamą ịtaką mikroorganizmų veiklai ir kai kurių augalų rūšių augimui, todèl tiesioginis neapdorotų kavos tirščių įterpimas į dirvą gali turèti neigiamų padarinių. Nepaisant nepageidaujamų organinių junginių, esančių kavos tirščiuose, juose gausu

(C) 2021 Dovilè Ragauskaitè, Rasa Šlinkšienè. Leidèjas Vilniaus Gedimino technikos universitetas. Šis straipsnis yra atvirosios prieigos straipsnis, turintis Kūrybinių bendrijų (Creative Commons) licenciją (CC BY 4.0), kuri leidžia neribotą straipsnio ar jo dalių panaudą su privaloma sąlyga nurodyti autorių ir pirminị šaltinị. 
ir augalams augti reikalingų neorganinių elementų, todèl jie gali būti vertinga trąšų pramonės žaliava (Batish et al., 2008).

Kita organinès kilmès, nuolatos besikaupianti atliekinè žaliava yra biokuro pelenai, gaunami sudeginus ịvairias augalines liekanas. Priklausomai nuo biokatilinès konstrukcijos, deginamo augalo rūšies ir net augalo dalies, degimo metu susidarę produktai pasižymi skirtingomis fizikinèmis bei cheminèmis savybèmis ir tai nulemia jų kokybę bei tolesnį naudojimą. Deginant biokurą, dèl aukštos proceso temperatūros dujų pavidalu išsiskiria ịvairių azoto oksidų ir augaluose esanti organinè anglis. Pelenuose yra daug kalcio, magnio, fosforo, aliuminio. Taip pat aptinkama ir geležies, cinko, nikelio, chromo, vario, boro ir sieros (Insam ir Knapp, 2011).

Šio darbo tikslas - ištirti ir įvertinti kavos tirščiu (KT) ir grikių lukšttu pelenų (GLP) naudojimo galimybes biriosioms trąšoms gaminti.

Kadangi granuliuoto produkto kokybè priklauso ne tik nuo granuliavimo parametrų, bet ir nuo žaliavų, buvo išanalizuotos ir ịvertintos kai kurios fizikinès bei cheminès KT ir GLP savybès. Tyrimo metu nustatytos optimalios granuliavimo sąlygos (kavos ir pelenų santykis, drègmès kiekis, drèkiklio-rišiklio prigimtis ir koncentracija). Laboratorinėmis sąlygomis buvo sugranuliuotos trąšos ir ištirtos gauto granuliuoto produkto fizikinès savybès: granuliometrinè sudètis, piltinis tankis, drégmės kiekis, prekinès frakcijos granulių stipris bei $10 \%$ vandeninio tirpalo $\mathrm{pH}$ vertès.

\section{Metodika}

Tyrimai atlikti 2020-2021 m. Trąšų technologijos laboratorijoje, esančioje KTU Cheminès technologijos fakultete. Šiame darbe naudoti kavos tirščiai buvo surinkti 20202021 m. Kauno mieste esančiose CAIF CAFE kavinèse. Kita tyrime naudota organinès kilmès medžiaga: grikiu lukštų pelenai, buvo gauti iš įmonès UAB „Ekofrisa“. Granuliavimo proceso metu drèkinamosiomis ir rišamosiomis medžiagomis buvo naudojamas vanduo, $85 \%$ ortofosforo rūgštis (gamintojas UAB „Eurochemicals“) ir cukraus pramonès atlieka - melasa (gamintojas UAB ,Lietuvos cukrus"). Kitos tyrimo metu naudotos cheminès medžiagos: kalio chloridas (gamintojas - UAB „Eurochemicals“, cheminis grynumas - min. 99,9\%).

Pradinių žaliavų, jų mišinio ir galutinio produkto drègmès kiekis nustatytas naudojant elektronini drégmès analizatorių KERN MLS 50-3HA160N (Vokietija).

Naudojantis „HANNA instruments pH 211 microprocessor" pH matuokliu (Jungtinès Amerikos Valstijos) buvo nustatytos tirpalų $\mathrm{pH}$ vertès. Dirvožemio $\mathrm{pH}$ vertės matavimai buvo atlikti pagal LST ISO 10390:2005 (Lietuvos standartizacijos departamentas, 2005) standartą, naudojant $1 \mathrm{~mol} / \mathrm{l}$ koncentracijos kalio chlorido tirpalą. Suspensija ruošiama dirvožemị užpilant kalio chlorido tirpalu santykiu 1:5 (tūrio dalimis). Laikoma ne mažiau negu 2 val., nuolatos maišant. Praejjus nurodytam laikui matuojama suspensijos $\mathrm{pH}$ vertè. Grikių lukštų pelenų $\mathrm{pH}$ vertei nustatyti buvo paruošti $2 \%, 10 \%$ ir $20 \%$ koncentracijos vandeniniai tirpalai. Gauta suspensija filtruojama per $2-$ $3 \mu \mathrm{m}$ porų skersmens filtrą mèlyna juosta ir matuojama filtrato $\mathrm{pH}$ verte. Granuliuoto produkto $\mathrm{pH}$ nustatyti buvo ruošiamas $10 \%$ koncentracijos tirpalas distiliuotame vandenyje, o tolesnè $\mathrm{pH}$ vertès matavimo eiga yra analogiška kaip GLP.

Tiriant KT cheminę sudèti pagal modifikuotą LST EN 13039:2012 (Lietuvos standartizacijos departamentas, 2012) standartą, buvo nustatytas organinių medžiagų ir pelenų kiekis. Analizuojami bandiniai ir tiglis išdžiovinami, pasveriami $\pm 0,001 \mathrm{~g}$ tikslumu ir deginami $900{ }^{\circ} \mathrm{C}$ temperatūroje, pagal masės nuostolị apskaičiuojama organinių medžiagų kiekis:

$$
C_{\text {org. }}=\frac{m_{1}-m_{2}}{m_{1}-m_{0}}, \%
$$

čia $m_{1}-$ išdžiovintos medžiagos ir tiglio masè, g; $m_{2}$-medžiagos ir tiglio masè po deginimo; $m_{0}-$ tiglio masè, $\mathrm{g}$.

Kavos tirščiu granuliavimas su kitais organinès kilmès priedais buvo atliktas naudojant laboratorinị būgnini granuliatorių-džiovyklą (BGD), kurio būgno posvyrio kampas $3^{\circ}$, sukimosi greitis - 20 aps./min. Principine BGD schema pateikta 1 pav. Proceso metu buvo palaikoma $70-80^{\circ} \mathrm{C}$ temperatūra (Paleckienè et al., 2012).

Piltinis granuliuoto produkto tankis nustatytas pagal LR standartą LST EN 1235:2002/A1:2005 (Lietuvos standartizacijos departamentas, 2005). Pirmiausia elektroninèmis svarstyklëmis KERN EW/EG-(N) (Vokietija) $\pm 0,001 \mathrm{~g}$ tikslumu pasveriamas tuščias graduotas matavimo cilindras, o paskui cilindras su granulemis. Laisvai supiltų trąšu piltinis tankis (toliau - piltinis tankis) apskaičiuojamas pagal formulę:

$$
\rho_{\text {pilt. }}=\frac{m_{2}-m_{1}}{V}, \mathrm{~kg} / \mathrm{m}^{3}
$$

čia $m_{1}$ - tuščio cilindro masè; $m_{2}-$ cilindro su granulèmis masè; $V$-matavimo cilindro tūris.

Granuliometrinè sudètis nustatyta naudojant skirtingo skersmens akučių sietų komplektą LST EN 1236:2002 (Lietuvos standartizacijos departamentas, 2002). Kiekvienos frakcijos masei nustatyti naudotos 


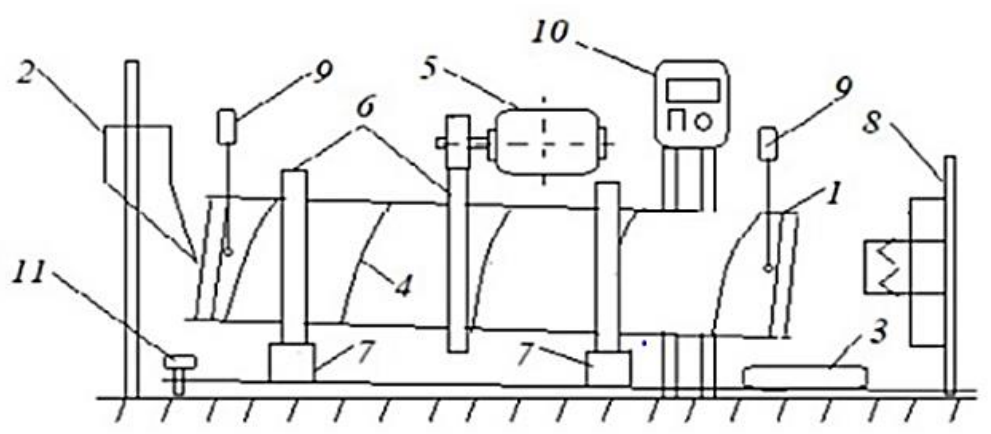

1 paveikslas. Principinè laboratorinio būgninio granuliatoriaus-džiovyklos schema: 1 - granuliatoriaus būgnas; 2 - žaliavų tiekimo anga; 3 - produkto išbyrejjimo anga; 4 - mentelès; 5 - elektros variklis; 6 - krumpliaratis; 7 - atraminis ritinys; 8 - karšto oro tiekimas; 9 - termoporos; 10 - valdymo pultas; 11 - posvyrio kampo fiksatorius

KERN EW/EG-(N) svarstyklès. Frakcijos kiekis yra išreiškiamas procentais pagal formulę:

$$
X_{n}=\frac{m_{n}}{M}, \%
$$

čia $m_{n}$ - atitinkamos frakcijos masè, g; $M$ - bendra viso bandinio masè, $g$.

Statinis granulių stipris išreiškiamas kaip jèga, reikalinga granulei sutraiškyti. Matavimams naudojama tik prekine frakcija, sudaryta iš $2-3 \mathrm{~mm}$ ir $3-5 \mathrm{~mm}$ skersmens granulių. Iš kiekvienos frakcijos atrenkama ne mažiau negu 20 panašios formos ir dydžio granulių. Jèga, reikalinga granulei sutraiškyti, nustatyta naudojant IPG-2 (Rusija) prietaisą (Šlinkšienè ir Paleckienè, 2018).

Rezultatų patikimumui įvertinti apskaičiuotas standartinis nuokrypis naudojant „Microsoft Office“ programy paketo „Excel“ programos STDEV funkciją.

\section{Rezultatai ir jų analizė}

Kavos tirščių fizikinès ir cheminès savybès buvo išanalizuotos ir aprašytos ankstesniuose mūsų tyrimuose (Ragauskaite ir Šlinkšienè, 2020a). Tyrimų metu gauti rezultatai rodo, jog KT $10 \%$ vandeninis tirpalas nepasižymi stipriomis rūgštinėmis savybėmis, nes $\mathrm{pH}$ vertẻ siekia 5,6.

Šiame darbe buvo ištirta KT priedo įtaka dirvožemio pH vertes kitimui. İ žemę buvo ịterptas skirtingas tirščiu kiekis: $10 \%, 20 \%, 30 \%, 40 \%$ ir $50 \%$ nuo bendros mišinio masès. Mišiniai išlaikomi 20 dienų, nuolatos juos drèkinant vandeniu. Bandinių suspensijos $\mathrm{pH}$ vertés matuojamos po 10 bei 20 dienų, gauti rezultatai lyginami su kontroliniu bandiniu (1 lentelè). Po 10 dienų, suspensijos $\mathrm{pH}$ vertès vandenyje sumažèjo, lyginant su kontroliniu bandiniu. Iš rezultatų matyti, jog didejjant kavos tirščiu kiekiui mišinyje, suspensija rūgštejja, ir mišinio, sudaryto iš
$50 \%$ kavos tirščiu, pH verte siekia 6,7. Matavimus atlikus kalio chlorido tirpale, matyti, jog suspensijų $\mathrm{pH}$ vertès yra šiek tiek mažesnès negu vandenyje, ir kinta intervale 6,16,9. Po 20 dienų gauti rezultatai beveik nepasikeite, tiek matuojant vandenyje, tiek kalio chlorido tirpale. Gauti minimalūs skirtumai gali būti aiškinami prietaiso matavimo paklaida arba ne visiškai kokybiškai homogenizuotu žemių ir kavos tirščių mišiniu. Apibendrinant rezultatus, galima teigti, jog tirtomis sąlygomis kavos tirščiai kiek sumažino dirvožemio $\mathrm{pH}$ vertę.

Organinių medžiagų kiekis kavos tirščiuose buvo nustatytas sauso deginimo metodu, ir siekia 99,25\%, o mineralinè dalis (pelenai) sudaro $0,75 \%$.

Ankstesniuose mūsų tyrimuose buvo nustatytos ir kitų augalų maisto medžiagų (AMM) koncentracijos, gauti rezultatai leidžia teigti, jog AMM koncentracijos, esančios tirščiuose, yra nedidelès (Ragauskaitė ir Šlinkšiené, 2020a). Daugiausia aptinkama kalio, kurio koncentracija (perskaičiavus ị $\mathrm{K}_{2} \mathrm{O}$ ) siekia $2,17 \%$. Dèl nedidelių augalams reikalingų elementų koncentracijų KT nèra tikslinga naudoti kaip organinès kilmès trąšu be jokių papildomų priedų, todèl šiame darbe plačiau tirtos KT ir grikių lukštų pelenų naudojimo galimybẻs trąšoms gauti.

Remiantis skenuojančiosios elektroninès mikroskopijos duomenimis, grikių lukštų pelenuose yra 9-11 \% kalcio, kuris lemia šarmines biomasès pelenų savybes (Ragauskaitė ir Šlinkšienė, 2020b). Kadangi pH vertė turi itakos ne tik augalų augimui, bet ir visiems dirvožemyje vykstantiems procesams, buvo nustatytos ịvairiu koncentracijų GLP vandeninių tirpalų pH vertès (2 lentelè).

Iš gautų rezultatų matyti, jog pelenai pasižymi itin šarminèmis savybèmis, $10 \%$ tirpalo $\mathrm{pH}$ verté siekia 10,7 . Didinant pelenų kiekį, ši verte tolygiai didèja, t. y. tirpalas šarmejja. 
1 lentelè. Dirvožemio ir kavos tirščių mišinio tirpalų pH vertès

\begin{tabular}{|c|c|c|c|c|c|c|c|c|c|c|}
\hline \multirow{5}{*}{$\begin{array}{l}\text { Eksperimento } \\
\text { trukmé }\end{array}$} & \multicolumn{5}{|c|}{$\mathrm{pH}$} & \multicolumn{5}{|c|}{$\mathrm{pH}_{\mathrm{KCl}}$} \\
\hline & \multicolumn{10}{|c|}{ Kontrolè } \\
\hline & \multicolumn{5}{|c|}{7,6} & \multicolumn{5}{|c|}{7,0} \\
\hline & \multicolumn{10}{|c|}{ Kavos tirščių kiekis mišinyje (v/v, \%) } \\
\hline & 10 & 20 & 30 & 40 & 50 & 10 & 20 & 30 & 40 & 50 \\
\hline 10 dienų & 7,3 & 7,0 & 6,9 & 6,9 & 6,7 & 6,9 & 6,7 & 6,3 & 6,3 & 6,1 \\
\hline 20 dienų & 7,3 & 7,1 & 6,9 & 6,8 & 6,8 & 6,9 & 6,8 & 6,6 & 6,4 & 6,1 \\
\hline
\end{tabular}

2 lentelè. Grikių lukštų pelenų vandeninių tirpalų pH vertès

\begin{tabular}{|c|c|c|}
\hline \multirow{3}{*}{$\begin{array}{c}\text { Tirpalo koncentra- } \\
\text { cija, } \%\end{array}$} & \multicolumn{2}{|c|}{ Naudoto vandens temperatūra, ${ }^{\circ} \mathrm{C}$} \\
\hline & 22 & 100 \\
\hline & \multicolumn{2}{|c|}{$\mathrm{pH}$} \\
\hline 2 & 10,5 & 10,5 \\
\hline 10 & 10,6 & 10,7 \\
\hline 20 & 10,7 & 10,8 \\
\hline
\end{tabular}

Vertinant analizuoti naudoto vandens temperatūrą, matoma, jog ji neturi jokios įtakos vandeninio tirpalo $\mathrm{pH}$ vertei.

Ankstesnių tyrimų rezultatai leidžia daryti išvadą, jog kavos tirščiai nėra pakankamai plastiška, lengvai besigranuliuojanti medžiaga (Ragauskaitè ir Šlinkšienè, 2020a). Šio tyrimo metu žaliavų mišinys granuliuoti buvo ruošiamas iš grikių lukštų pelenų ir drègnų kavos tirščių, taip išvengiant papildomų energinių sąnaudų KT džiovinti. Papildomai buvo naudojamos drèkinamosios ir rišamosios medžiagos: vanduo, ortofosforo rūgštis, melasa.

Pirmiausia kavos tirščius buvo bandoma sumaišyti su grikių lukštų pelenais santykiu 1:1 ir drèkinti naudoti $1 \%$ ortofosforo rūgšties tirpalą vandenyje, tačiau granuliavimo metu granulès nesusiformavo ir pradinès žaliavos buvo išpučiamos iš granuliatoriaus. Kita granuliavimo bandinių serija buvo paruošta išlaikant tą pati pradinių žaliavų santyki, tačiau kaip drèkinamoji ir rišamoji medžiaga buvo naudojamas $10 \%$ melasos tirpalas vandenyje. Granulès susidarè, tačiau paliestos iškart sutrupèjo. Tolesniems bandymams buvo naudojamas $20 \%$ ir $40 \%$ melasos tirpalas vandenyje, tačiau gautas rezultatas buvo analogiškas kaip ir naudojant $10 \%$ melasos tirpalo koncentraciją. Galima daryti išvadą, jog pradinių žaliavų mišinys yra per mažai plastiškas, jame veikiančios adhezijos ir kohezijos jègos yra per silpnos granulèms susiformuoti.

Kitiems bandiniams buvo naudojamas KT:GLP = 2:3 santykis, o melasos tirpalo vandenyje koncentracija -
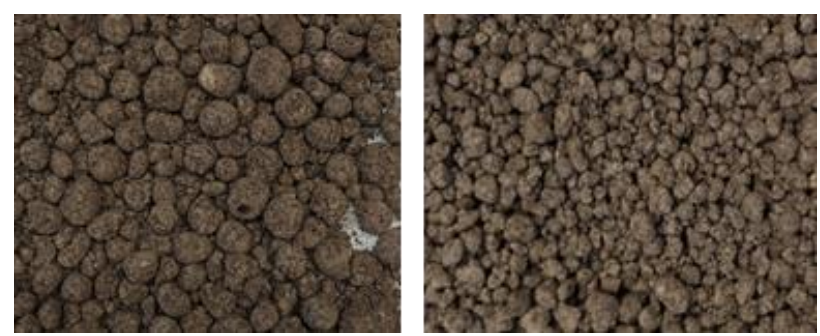

2 paveikslas. Granuliuotas produktas, gautas granuliuojant santykiu KT:GLP $=2: 3$ ir drékinti naudojant $40 \%$ melasos tirpalą vandenyje

$40 \%$. Naudojant tokị pradinių žaliavų santykị granulès susiformavo (2 pav.), tačiau jų stipris buvo mažesnis negu prietaiso nustatymo riba ( $5 \mathrm{~N} /$ granulei).

Kadangi gautas produktas neatitiko trąšoms keliamų reikalavimų, buvo įvertinta tik $10 \%$ tirpalo pH verte, kuri siekè 10,6, o kitos fizikinès savybès nebuvo nustatytos.

Toliau tyrimai buvo tęsiami keičiant pradinių žaliavų santykį, taip pat drèkiklio-rišiklio koncentraciją ir cheminę sudèti. Buvo nustatyta, jog tinkamiausiomis fizinèmis savybėmis pasižymi produktas, gautas naudojant $\mathrm{KT}: \mathrm{GLP}=1: 4$ bei $40 \%$ melasos tirpalą $21 \%$ ortofosforo rūgšties tirpale. Granuliuoti naudotų surinktų KT drègmè $51 \%$, o pradinè žaliavų mišinio drègmè prieš granuliavimą $-11,8 \%$. Granuliometrinè gauto produkto sudètis pateikta 3 pav.

Analizuojant gautus rezultatus, matyti, jog maksimalus prekinès frakcijos, kuri yra sudaryta iš $2-3 \mathrm{~mm}$ ir $3-$ $5 \mathrm{~mm}$ dydžio granulių, kiekis susidaro, kai bendra granuliuoti naudojamo mišinio drègmè su drèkikliu sudaro $62,66 \%$. Gautame produkte prekinès frakcijos kiekis siekia $77 \%$ ir joje tolygiai pasiskirsčiusios $2-3 \mathrm{~mm}$ ir 3$5 \mathrm{~mm}$ skersmens dydžio dalelès $(\sim 38 \%$ kiekvienos frakcijos). Šiek tiek mažesnis prekinès frakcijos kiekis $(74,50 \%)$ susidarè naudojant mišinị su $62,37 \%$ drègmès kiekiu. 


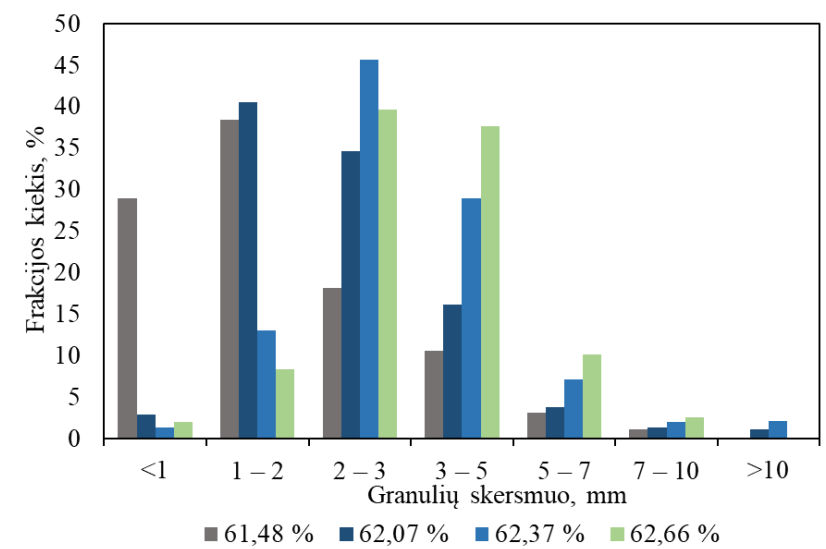

3 paveikslas. Granuliometrinè sudètis produkto, gauto granuliuojant santykiu KT:GLP = 1:4 ir drékinimui naudojant $40 \%$ melasos tirpalą $21 \%$ fosforo rūgštyje

Fizikinès gauto granuliuoto produkto savybės pateikiamos 3 lentelèje. Analizuojant gautus rezultatus matyti, kad išdžiovinto iki pastovios masès produkto drégmè svyruoja 3,21-3,96\% intervale, gautų granulių piltinis tankis - nuo $433,8 \mathrm{~kg} / \mathrm{m}^{3}$ iki $514,0 \mathrm{~kg} / \mathrm{m}^{3}$. Lyginant $10 \%$ vandeninių tirpalų $\mathrm{pH}$ vertes, matyti, kad jos praktiškai vienodos ir panašios kaip ir granuliuojant mišinį, kuriame KT ir GLP santykis 2:3. Nepaisant didesnio pelenų kiekio, naudoto pradiniame žaliavų mišinyje, panašios $\mathrm{pH}$ vertès gaunamos dèl to, jog žaliavų mišinyje esantys pelenai yra neutralizuojami $\mathrm{H}_{3} \mathrm{PO}_{4}$. Susidariusių 2-5 mm dydžio granulių stipris kinta 6,96-10,20 N/granulei.

3 lentelè. Fizikinès savybės granuliuoto produkto, gauto esant santykiui KT:GLP = 1:4 ir drèkinimui naudojant $40 \%$ melasos tirpalą $21 \%$ fosforo rūgštyje

\begin{tabular}{|c|c|c|c|c|c|}
\hline \multirow{3}{*}{ 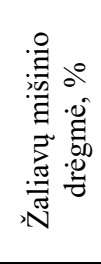 } & \multicolumn{5}{|c|}{ Granuliuoto produkto fizikinès savybès } \\
\hline & \multirow[b]{2}{*}{ 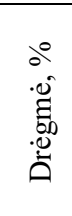 } & \multirow{2}{*}{ 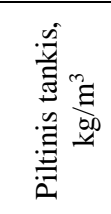 } & \multirow{2}{*}{ 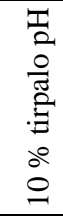 } & \multicolumn{2}{|c|}{ Stipris, N/granulei } \\
\hline & & & & $2-3 \mathrm{~mm}$ & $3-5 \mathrm{~mm}$ \\
\hline 61,48 & 3,96 & 433,8 & 10,6 & $8,04 \pm 1,9$ & $10,20 \pm 2,1$ \\
\hline 62,07 & 3,21 & 494,1 & 10,6 & $7,19 \pm 1,7$ & $7,42 \pm 1,3$ \\
\hline 62,37 & 3,52 & 492,4 & 10,6 & $6,96 \pm 1,6$ & $7,10 \pm 2,1$ \\
\hline 62,66 & 3,86 & 514,0 & 10,7 & $8,87 \pm 2,4$ & $9,17 \pm 2,3$ \\
\hline
\end{tabular}

Granuliavimo metu susidaro dideli kiekiai $<2 \mathrm{~mm}$ ir $>5 \mathrm{~mm}$ frakcijų, kurios bendrai yra vadinamos returu. Išdžiovinus granules iki pastovios masès, atskyrus prekinę frakciją, likusios netinkamo dydžio dalelès buvo surenkamos, susmulkinamos iki mažesnio negu $1 \mathrm{~mm}$ skersmens dalelių ir naudojamos tolesniuose tyrimuose, kaip returas.
Buvo paruošti žaliavų mišiniai, kuriuose returo kiekis sudare $20 \%$ nuo bendros pradinio žaliavų mišinio masès. Pradinių medžiagu santykis ir drèkiklis buvo toks pat. Buvo nustatyta, kad granuliuoti naudojant $20 \%$ returo, vandeninių tirpalų $\mathrm{pH}$ vertès kito 10,4-10,5, o gautų granulių stipris siekè $10,78 \pm 2,9 \mathrm{~N} /$ granulei. I pradinį mišini itterpus dar didesnị returo kieki $-40 \%$, susidariusių granulių stipris $(11,47 \pm 1,6 \mathrm{~N} /$ granulei) ir $10 \%$ vandeninio tirpalo $\mathrm{pH}$ vertè - 10,4. Šio vertès išliko panašios kaip ir produktui granuliuoti naudojant $20 \%$ returo žaliavų mišinyje. Tęsiant tyrimus, ị pradinị žaliavų mišinị buvo įdeta $60 \%$ returo. Gauta granuliometrinè sudètis pateikta 4 pav. Kaip matyti iš pateiktų rezultatų, maksimalus prekinès frakcijos kiekis (69\%) gautas granuliuojant žaliavų mišini, kuriame drègmès kiekis yra lygus $47,11 \%$. Šiomis sąlygomis prekineje frakcijoje vyrauja $2-3 \mathrm{~mm}$ skersmens granulès.

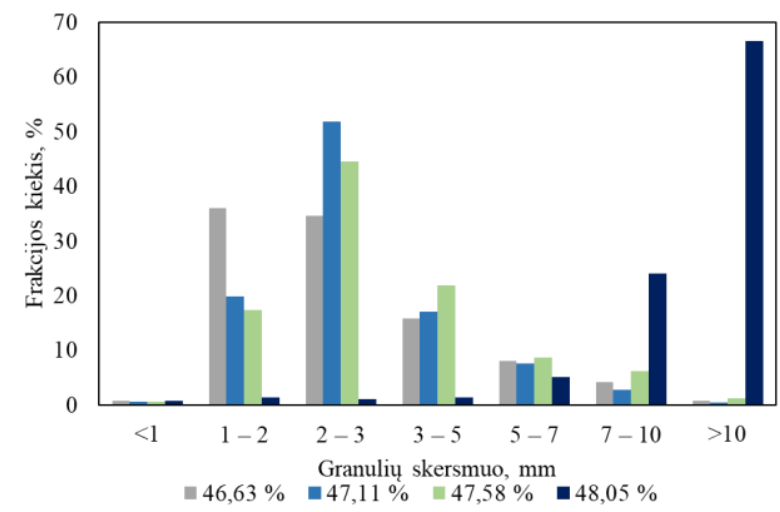

4 paveikslas. Granuliometrinè sudètis produkto, gauto granuliuojant santykiu KT:GLP $=1: 4$ su $60 \%$ returo ir drékinti naudojant $40 \%$ melasos tirpalą $21 \%$ fosforo rūgštyje

Granuliuojant tokios pradinès sudèties žaliavų mišinį, beveik nesusidare smulkiausios ( $<1 \mathrm{~mm}$ dydžio) frakcijos. Vizualiai vertinant gautas granules (5 pav.), matyti, jog jos yra sferinès formos ir lygaus paviršiaus.
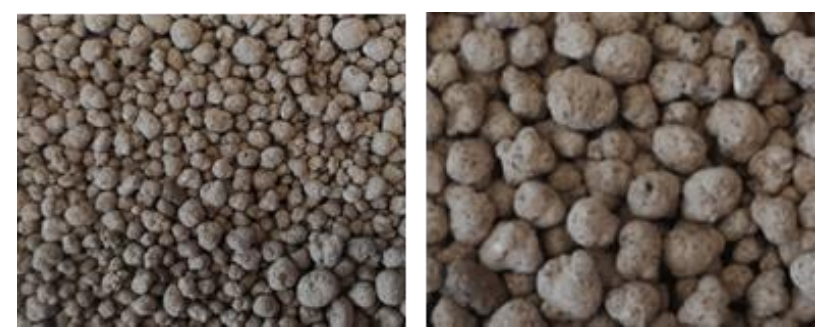

5 paveikslas. Granuliuotas produktas, gautas granuliuojant santykiu KT:GLP = 1:4 su $60 \%$ returo ir drékinti naudojant $40 \%$ melasos tirpalą $21 \%$ fosforo rūgštyje 
Vertinant fizikinių savybių pokytị (4 lentelè) nustatyta, jog granuliuojant mišinị su $60 \%$ returo kiekiu, granulių stipris iš esmès nepakito, lyginant su anksčiau gautais rezultatais. Tačiau gautas produktas pasižymi silpnesnèmis šarminèmis savybėmis, gauto vandeninio $10 \%$ tirpalo $\mathrm{pH}$ vertės kinta 8,1-8,6 intervale. Didžiausias piltinis prekinès frakcijos granulių tankis siekia $555,2 \mathrm{~kg} / \mathrm{m}^{3}$.

4 lentelè. Fizikinès savybès produkto, gauto granuliuojant santykiu KT:GLP $=1: 4$ su $60 \%$ returo ir drèkinti naudojant $40 \%$ melasos tirpalą $21 \%$ fosforo rūgštyje

\begin{tabular}{|c|c|c|c|c|c|}
\hline \multirow{3}{*}{ 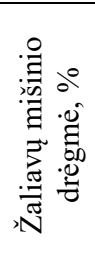 } & \multicolumn{5}{|c|}{ Granuliuoto produkto fizikinès savybès } \\
\hline & \multirow{2}{*}{ 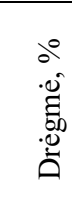 } & \multirow{2}{*}{ 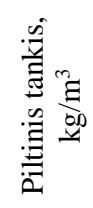 } & \multirow{2}{*}{ 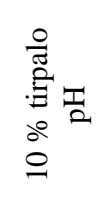 } & \multicolumn{2}{|c|}{ Stipris, N/granulei } \\
\hline & & & & $2-3 \mathrm{~mm}$ & $3-5 \mathrm{~mm}$ \\
\hline 46,63 & 4,43 & 555,2 & 8,6 & $10,19 \pm 2,9$ & $10,73 \pm 2,1$ \\
\hline 47,11 & 4,52 & 524,4 & 8,3 & $10,11 \pm 2,6$ & $9,02 \pm 1,9$ \\
\hline 47,58 & 4,59 & 544,8 & 8,1 & $10,05 \pm 2,2$ & $10,44 \pm 2,1$ \\
\hline 48,05 & 4,81 & - & - & - & - \\
\hline
\end{tabular}

Apibendrinant gautus rezultatus galima daryti išvadą, jog papildomas ị mišini ịvedamo returo kiekis ne tik sumažina susidariusių nepageidaujamo dydžio granulių kiekį, taip užtikrinant sąlygas vykdyti beatliekį, uždarą technologini procesą, bet ir pagerina produkto fizikines savybes. Gautos granulès pasižymi didesniu stipriu, piltiniu tankiu, taip pat mažesne $\mathrm{pH}$ verte. Be to, pradiniam mišiniui gauti naudojamo returo kiekis turi įtakos ir drekkiklio-rišiklio kiekiui, t. y. didinant returo kieki, reikalingas drékiklio-rišiklio kiekis tolygiai mažèja, o tai mažina žaliavų poreikị, trumpina produkto džiovinimo trukmę, mažina energijos sąnaudas ir pigina produkciją.

\section{Išvados}

1. Analizuojant kavos tirščiu įtaką dirvožemio pH vertei, nustatyta, kad įterpiant ị dirvožemị KT, pH verte nežymiai sumažěja.

2. Organinių medžiagų kiekis kavos tirščiuose siekia $99,25 \%$.

3. Nustatyta, jog optimaliausi granuliavimo parametrai yra: KT:GLP santykis 1:4; $60 \%$ returo, papildomam sauso žaliavų mišinio drèkinimui naudojama 36,83\% (skaičiuojant nuo bendros sausojo mišinio masès) $40 \%$ melasos tirpalo $21 \%$ fosforo rūgštyje.

4. Optimaliomis granuliavimo sąlygomis gauto produkto fizikinès savybès: granulių stipris -
$10,11 \pm 2,6 \mathrm{~N} /$ granulei; $10 \%$ tirpalo $\mathrm{pH}$ vertè lygi 8,3; piltinis tankis $524,4 \mathrm{~kg} / \mathrm{m}^{3}$; drègmès kiekis išdžiovintame produkte $-4,52 \%$.

\section{Padéka}

Iš dalies šiuos tyrimus finansavo Lietuvos mokslo taryba (LMTLT), sutarties Nr. 09.3.3-LMT-K-712-22-0055.

\section{Literatūra}

Batish, D. R., Singh, H. P., Kaur, M., Kohli, R. K., \& Yadav, S. S. (2008). Caffeine affects adventitious rooting and causes biochemical changes in the hypocotyl cuttings of mung bean (Phaseolus aureus Roxb.). Acta Physiologiae Plantarum, 30(3), 401405. https://doi.org/10.1007/s11738-007-0132-4

Blinová, L., Sirotiak, M., Bartošová, A., \& Soldán, M. (2017). Review: Utilization of waste from coffee production. $R e$ search Papers, Faculty of Materials Science and Technology, Slovak University of Technology, 25(40), 91-101. https://doi.org/10.1515/rput-2017-0011

Gomes, T., Pereira, J. A., Ramalhosa, E., Casal, S., \& Baptista, P. (2013). Effect of fresh and composted spent coffee grounds on lettuce growth, photosynthetic pigments and mineral composition. In VII Congreso Ibérico de Agroingenieria y Ciencias Horticolas, Madrid. SECH e SEAgIng. http://hdl.handle.net/10198/8719

Insam, H., \& Knapp, B. A. (Eds) (2011). Recycling of biomass ashes. Springer. https://doi.org/10.1007/978-3-642-19354-5

International Coffee Organization. (2021). http://www.ico.org/prices/po-production.pdf

Leifa, F., Pandey, A., \& Soccol, C. R. (2001). Production of Flammulina velutipes on coffee husk and coffee spentground. Brazilian Archives of Biology and Technology, 44(2), 205-212.

https://doi.org/10.1590/S1516-89132001000200015

Lietuvos standartizacijos departamentas. (2002). Kietosios trąšos. Trąšu granuliometrinès sudeties nustatymas sijojant (LST EN 1236:2002).

Lietuvos Standartizacijos departamentas. (2005). Dirvožemio kokybe. pH nustatymas (tapatus ISO 10390:2005) (LST ISO 10390:2005).

Lietuvos standartizacijos departamentas. (2005). Trąšos. Laisvai supiltu trąšu piltinio tankio nustatymas (LST EN 1235:2002/A1:2005).

Lietuvos standartizacijos departamentas. (2012). Dirvožemio gerinimo medžiagos ir auginimo terpés. Organinių medžiagu ir pelenu kiekio nustatymas (LST EN 13039:2012).

Nosek, R., Tun, M., \& Juchelková, D. (2020). Energy utilization of spent coffee grounds in the form of pellets. Energies, 13(5), 1235. https://doi.org/10.3390/en13051235

Paleckienè, R., Sviklas, A., Šlinkšienè, R., \& Štreimikis, V. (2012). Processing of rape straw ash into compound fertilizers using sugar factory waste. Polish Journal of Environmental Studies, 21(4), 993-999.

https://www.researchgate.net/publication/288242162_Processing_of_Rape_Straw_Ash_into_Compound_Fertilizers_Using_Sugar_Factory_Waste 
Ragauskaitè, D. ir Šlinkšienè, R. (2020a). Kavos tirščių panaudojimo organinèms trąšoms gaminti galimybès. Žemès ūkio mokslai, 27(2), 141-148.

https://doi.org/10.6001/zemesukiomokslai.v27i2.4336

Ragauskaitè, D., \& Šlinkšienè, R. (2020b). Fly ashes physical properties and chemical composition. In $22^{\text {nd }}$ International Conference - School "Advanced Materials and Technologies 2020". Palanga, Lithuania.

Šlinkšienè, R. ir Paleckienè, R. (2018). Trąšos. Gavimas ir analizé. Technologija.

https://doi.org/10.5755/e01.9786090214701
PRODUCTION OF GRANULAR FERTILIZERS FROM ORGANIC WASTE

D. Ragauskaitè, R. Šlinkšienè

Summary

According to the International Coffee Organization $10^{7}$ kilograms of coffee beans have been consumed during 2020 and most of it in Europe. During the initial coffee harvesting and coffee beverage preparation lots of by-products are being obtained, such as: pulp, silverskin, husks, spent coffee grounds. Considering the concentration of chemical elements in coffee waste, these by-products are not being used properly in development of new products or materials. In this thesis, possibilities of making granular fertilizers made of spent coffee grounds, were analysed and evaluated.

Coffee ground were collected from coffee shops located in Kaunas and without any further processing (drying stage) were granulated with laboratory granulator-drier. The results showed that the granules made of coffee grounds did not meet the requirements for granular fertilizers. To improve the chemical composition and physical properties of the granules other organic substances were added.

Keywords: coffee grounds, buckwheat husks, granulation, molasses. 